\title{
SUSCEPTIBILITY LEVEL OF THE POLLEN BEETLE (MELIGETHES AENEUS F.) TO SELECTED PYRETHROIDS IN POLAND, AND RESISTANCE MECHANISMS OF THE PEST TO DELTAMETHRIN
}

\author{
Joanna Zamojska ${ }^{1 *}$, Pawet Wegorek ${ }^{1}$, Marek Mrówczyński
}

Institute of Plant Protection - National Research Institute

Władysława Węgorka 20, 60-318 Poznań, Poland

${ }^{1}$ Department of Zoology

${ }^{2}$ Department of Pesticide Investigation, Research Team for Zoocide Efficacy

Received: September 20, 2012

Accepted: January 31, 2013

\begin{abstract}
Pollen beetle susceptibility level to different insecticides has been investigated in Poland for several years. So far, high resistance to many of the insecticides' active substances has been found. The work presents the current status of the pollen beetle susceptibility level to deltamethrin and beta-cyfluthrin, pointing to the beetle's medium, high or very high resistance to both active substances. Also, pollen beetle resistance mechanisms to deltamethrin were investigated. Research, conducted with the use of oxidases, esterases and glutathione transferases blockers, showed that all three enzymes groups are involved in the pollen beetle resistance mechanisms to deltamethrin. The main role was played by oxidases and to a lower degree: esterases and glutathione transferases, respectively.
\end{abstract}

Key words: pollen beetle, pyrethroids, resistance, resistance mechanisms, synergists

\section{INTRODUCTION}

Insect resistance to insecticides is one of the main problems in plant protection resulting in great yield losses. Presently one of the most important insect pests, known for its resistance to many active substances of insecticides, is the pollen beetle (Meligethes aeneus F.). The susceptibility level of the pest to different insecticides, especially to pyrethroids, has been widely investigated (Węgorek 2005; Hansen 2008; Richardson 2008; Węgorek and Zamojska 2008; Węgorek et al. 2009; Zamojska et al. 2010). The constant decrease in the susceptibility level of the pest to many active substances creates the need to monitor the resistance phenomenon. Deltamethrin and beta-cyfluthrin are very popular insecticides from the pyrethroid group which have been used against the pollen beetle since the beginning of the eighties and since the mid-nineties, respectively.

One of the most important insect resistance mechanisms to insecticides is the biotransformation of active substances involving three main enzyme groups: monooxigenases, esterases, and glutathione transferases (Ahmad 1986; Yu 1988; Malinowski 2003; Terra and Fereira 2005). The most common pollen beetle resistance mechanism to pyrethroids is the one based on monooxygenases, however, it is known that esterases also play a role in this process (Węgorek 2009; Philippou et al. 2010; Węgorek et al. 2011a).
The first aim of the study was to determine the current status of the pollen beetle susceptibility level to deltamethrin and beta-cyfluthrin. The second aim was to investigate the participation of all three enzyme groups (oxidases, esterases and glutathion transferases) in the process of the pest resistance to deltamethrin. To achieve the second aim, three enzymes blockers were used (Malinowski 2003), among them, S,S,S-tributylphosphorotrithioate (DEF) as an esterases blocker, and diethyl malonate (DEM) as a transferases blocker which were used on the pollen beetle for the first time.

\section{MATERIALS AND METHODS}

In the research, Insecticide Resistance Action Committee (IRAC) Susceptibility Test Method No. 7 was used. The method, thoroughly described earlier (Węgorek et al. 2011a), was adapted with slight modifications. Instead of filter paper, plant material (oilseed rape leaves and inflorescences) was used and $20 \mathrm{~g}$ of plant material was put inside each glass container used for testing.

Insecticides (commercially available products):

Insecticide concentrations in ppm were calculated, assuming that 2001 of water would be used per hectare.

- beta-cyfluthrin (Bulldock 025 EC - $25 \mathrm{~g}$ of active substance/ 11 of the product): recommended dose (in the years 2008-2010. Presently it is not recommended 
against pollen beetle, but still recommended against cabbage seed weevil, which is most often present on rape fields together with pollen beetle in Poland): $0.25 \mathrm{l} / \mathrm{ha}$, recommended concentration $31.25 \mathrm{ppm}$,

- deltamethrin (Decis 2.5 EC - 2.5\% of active substance): recommended dose: 0.2 1/ha, recommended concentration: 25 ppm.

Pollen beetle adults, together with the untreated plant material, were collected for testing from three populations in the Wielkopolska region in Poland: Września, Wałcz and Krotoszyn, in the years 2008-2010. Laboratory conditions and statistical calculations were consistent with the ones described for the colorado potato beetle in the Journal of Plant Protection Research (Węgorek et al. 2011b; Zamojska et al. 2011). Base on the percent mortality of the pollen beetle at each dose, lethal concentrations $\mathrm{LC}_{50}$ and LC95 were calculated.

Resistance coefficient values were calculated as follows:

resistance coefficient $(\mathrm{RC})=\mathrm{LC}_{95} /$ recommended field dose (with the assumption that the recommended field dose had resulted in $100 \%$ mortality of insects at registration time).

The following criteria for resistance assessment were assumed:

$$
\begin{array}{ll}
\mathrm{RC} \leq 1 & - \text { the lack of resistance } \\
\mathrm{RC}=1.1-2 & \text { - low resistance } \\
\mathrm{RC}=2,1-5 & \text { - medium resistance } \\
\mathrm{RC}=5.1-10 & \text { - high resistance } \\
\mathrm{RC}>10 & \text { - very high resistance. }
\end{array}
$$

Mechanisms of pollen beetle resistance to deltamethrin were tested using synergists which block three main enzyme groups (Malinowski 2003). The synergists used were:

- piperonyl butoxide (PBO) - oxidases blocker

- S,S,S-tributylphosphorotrithioate (DEF) - esterases blocker

- diethyl malonate (DEM) - glutathione transferases blocker.

The method was thoroughly described in the Journal of Plant Protection Research (Zamojska et al. 2011). The only difference is that PBO concentration as well as DEF and DEM concentrations were always 100 ppm. It was investigated earlier that these concentrations do not cause any insect mortality when they are applied alone, without insecticides.

The synergism coefficient (SC) values were calculated as follows:

$$
\begin{gathered}
\mathrm{SC}=\mathrm{LC} \text { of active substance alone/LC of active } \\
\text { substance with a synergist }
\end{gathered}
$$

The following criteria were accepted to asses synergism between deltamethrin and a given insecticide: $\mathrm{SC}<1-$ antagonism $\mathrm{SC}=1-$ the lack of synergism and the lack of antagonism SC $>1$ - synergism.

\section{RESULTS}

The pollen beetle susceptibility level to deltamethrin and beta-cyfluthrin was presented in table 1. Most often there was high resistance of the pest to these active substances. The range of $\mathrm{LC}_{50}$ for deltamethrin was from 20.12 ppm (Września in 2009) to 43.53 ppm (Września in 2008). $\mathrm{LC}_{50}$ values exceeded the concentration recommended in Poland (25 ppm) in seven cases (in 2008: Września and Krotoszyn; in 2009: Wałcz and Krotoszyn; in 2010: Września, Wałcz and Krotoszyn). The highest $\mathrm{LC}_{95}$ value (809.16 ppm) exceeded the recommended concentration 32 times, and was recorded for the population of Września in 2009. The lowest $\mathrm{LC}_{95}$ value (107.89 ppm), exceeded the recommended concentration 4.3 times, and was noted in Wałcz in 2008. Thus, all $\mathrm{LC}_{95}$ values exceeded the recommended concentration many times. Resistance coefficient values for deltamethrin, presented in table 1, point to the population of Września in 2008 and 2009 and the population of Krotoszyn in 2010, as having the highest resistance. High resistance was noted for Września in 2010, Wałcz in both 2009 and 2010, and Krotoszyn in 2008 and 2009. Only in one case - Wałcz in 2008, was there medium resistance recorded. There was no low resistance or the lack of resistance stated.

For beta-cyfluthrin, the $\mathrm{LC}_{50}$ values were between 16.35 ppm (Wałcz in 2009) and 133.38 ppm (Września in 2010). The values exceeded the recommended concentration (31.25 ppm) in five cases (in 2008: Września and Krotoszyn; in 2009: Września; in 2010: Września, Wałcz and Krotoszyn). The highest $\mathrm{LC}_{95}$ value was noted for Września in 2010: 7653.6 ppm. This value was over 200 times above the recommended concentration. The lowest $\mathrm{LC}_{95}$ value (191.56) exceeded the recommended concentration 5 times (Krotoszyn in 2008). Resistance coefficient values revealed very high resistance for Września in 2008, 2009, and 2010, and for Wałcz in 2010. Medium resistance was recorded only once - for Wałcz in 2008. In the remaining cases, high resistance to beta-cyfluthrin was stated.

Research on cooperation between oxidative enzyme blocker PBO and deltamethrin (Table 2, Fig. 1) showed a very strong synergistic action between the two substances. Synergism coefficient values calculated for $\mathrm{LC}_{50}$ were between 255.36 (Krotoszyn in 2009) and 821.39 (Wałcz in 2009). Synergism coefficient values calculated for $\mathrm{LC}_{95}$, also signaled strong synergism ranging between 11.3 (Krotoszyn in 2009) and 765.52 (Września in 2009).

Research on cooperation between deltamethrin and esterases blocker DEF also showed synergistic action, however, it was much less intensive than in the case of PBO. Synergism coefficient values for $\mathrm{LC}_{50}$ were placed between 1.87 (Września in 2009) and 7.25 (Wałcz in 2010). Synergism coefficient values for LC $_{95}$ were very similar: between 3.96 (Wałcz in 2010) and 10.26 (Września in 2009).

A similar situation was recorded in the research on the cooperation between deltamethrin and glutathione transferases' blocker DEM. Synergism coefficient values calculated for $\mathrm{LC}_{50}$ ranged between 1.46 (Września in 2009) and 3.89 (Wałcz in 2009). The values calculated for $\mathrm{LC}_{95}$ did not differ significantly and were placed between 1.99 (Krotoszyn in 2009) and 7.95 (Wałcz in 2009). Such results distinctly point to the synergistic action of both substances. 
$\underset{\substack{\infty \\ \infty}}{\infty}$

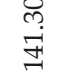

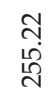

⿳亠 冋े

苞

$\overrightarrow{0}$
$\stackrel{0}{0}$

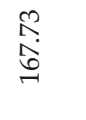

बे

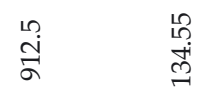

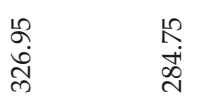

辛

$\stackrel{\circ}{\circ}$

赵

$\stackrel{\infty}{0}$
$\stackrel{\sim}{n}$

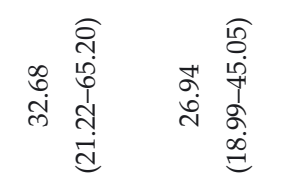

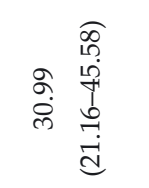

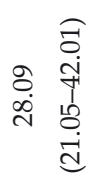

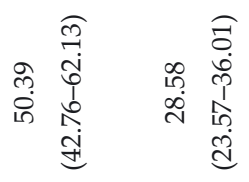

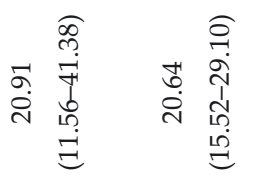

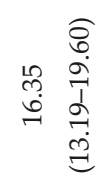

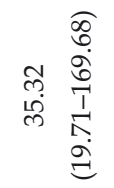

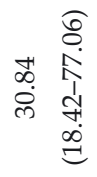

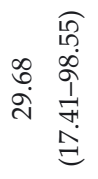

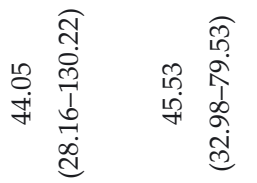

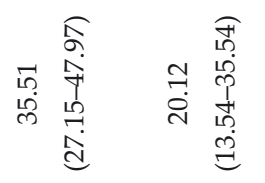

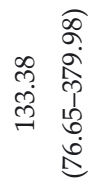

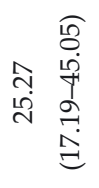

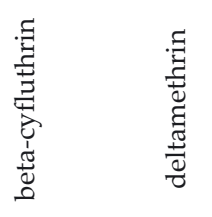

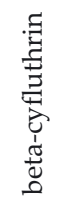

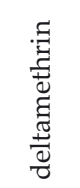

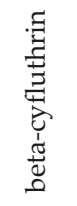

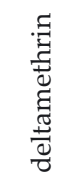

8002

6002

OLOZ 
:

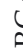

$\ddot{p}$

递

두

$3^{00}$

$\bigcup^{\dot{0}}$

需

产

莺

ํํำ

ठิे

范

$\stackrel{\vartheta}{\rightleftarrows}$

$\frac{\sqrt{3}}{\frac{3}{2}}$

过

몽

$\stackrel{g}{\Xi}$

हี

$\sum_{111}^{5}$

드

武

o

8

?.ّ.

$\stackrel{\Xi}{\Xi}$

ปั

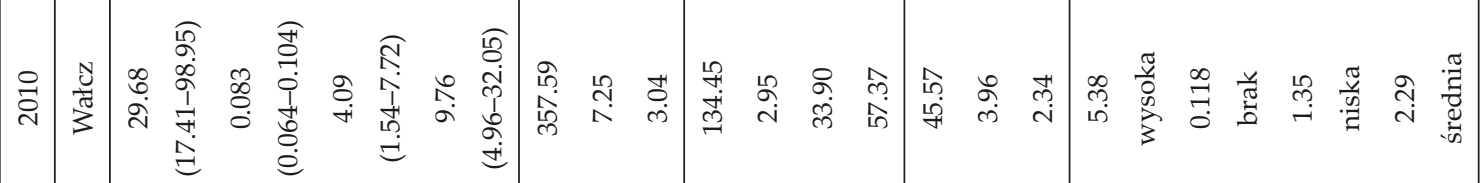

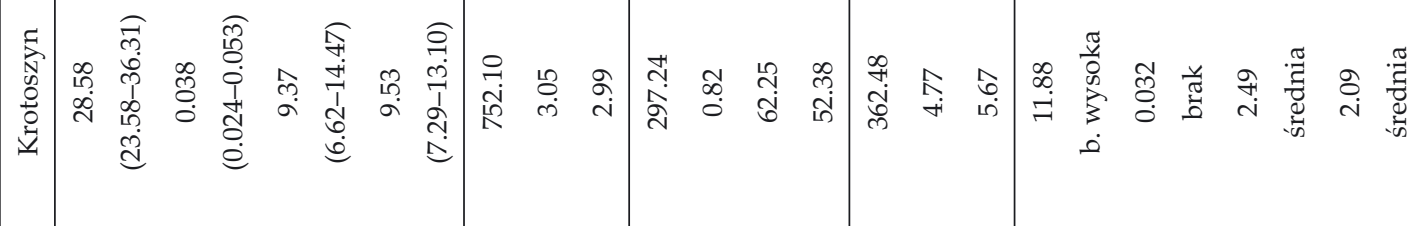

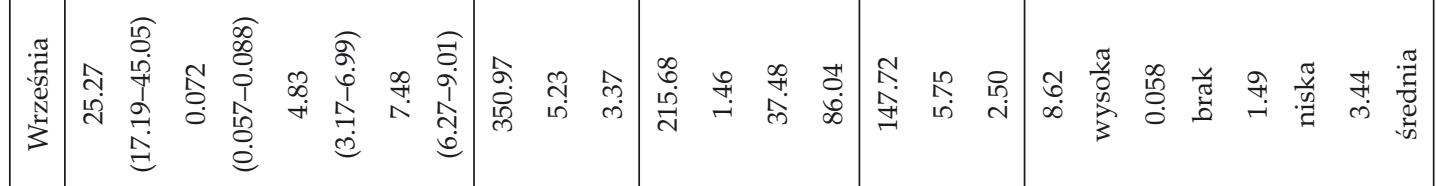

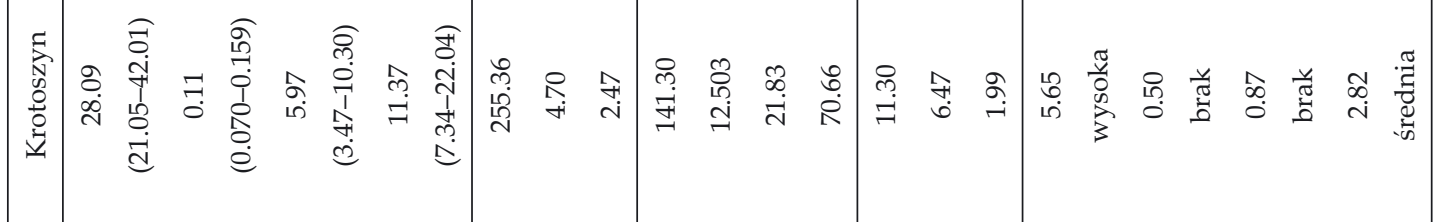

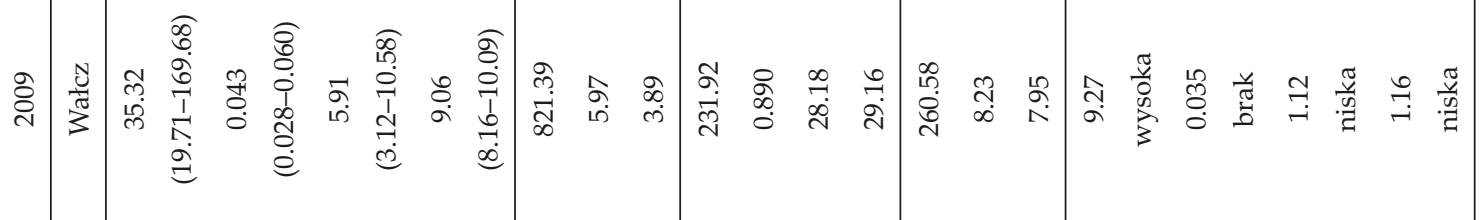

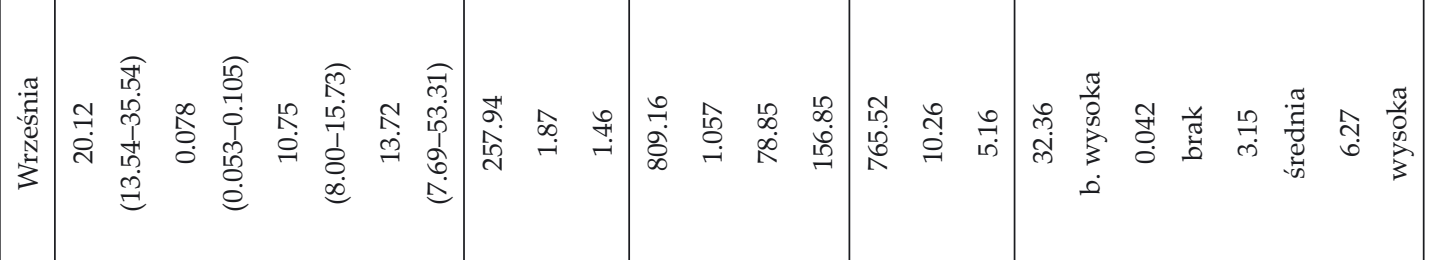

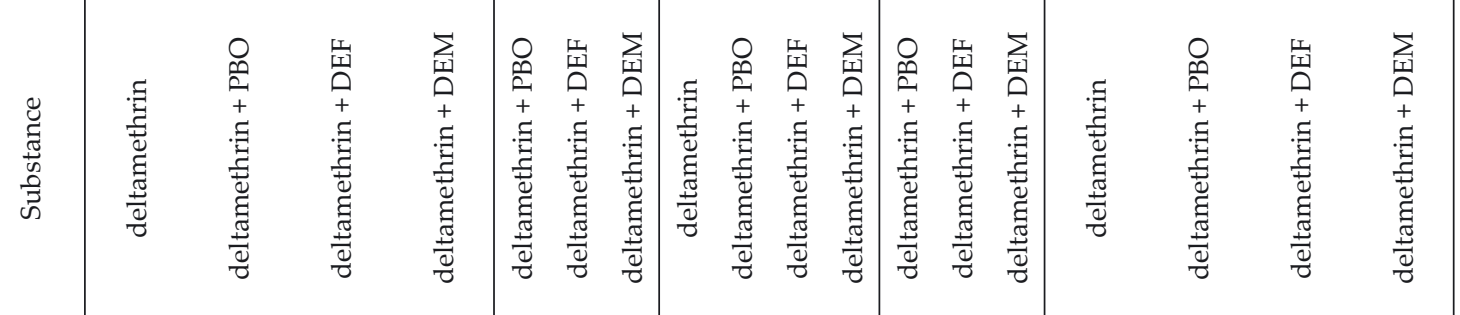

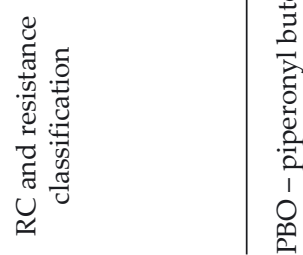




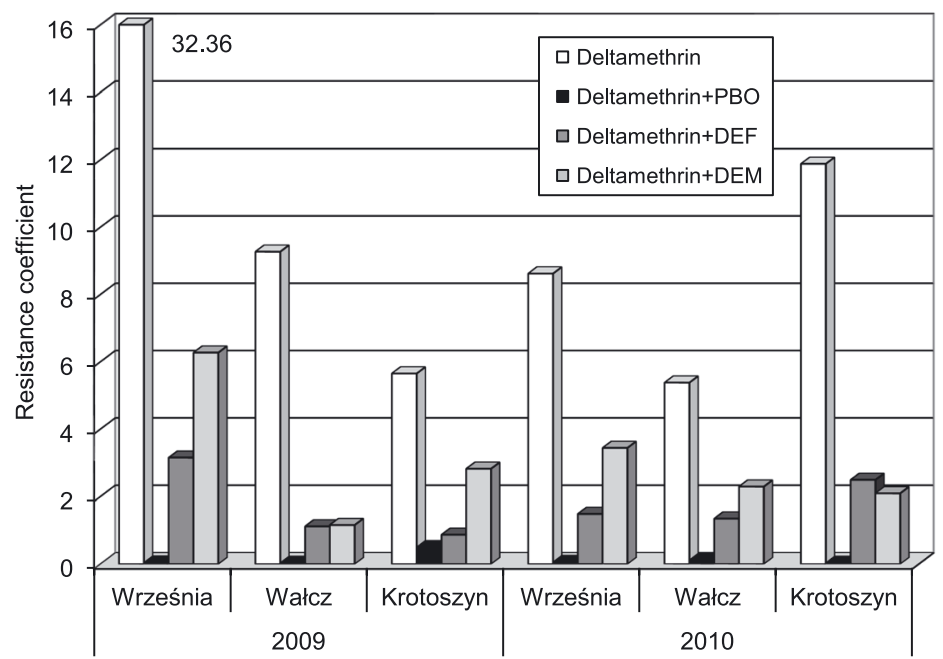

PBO - piperonyl butoxide; DEF - S,S,S-tributylphosphorotrithioate; DEM - diethyl malonate

Fig. 1. The influence of synergists on pollen beetle adult resistance to deltamethrin in the years 2009-2010

The presented results showed the highest synergistic cooperation between deltamethrin and PBO. It can be concluded, that the pollen beetle resistance mechanism to deltamethrin mainly involves oxidative enzymes, but the participation of esterases and glutathione transferases is also evident.

\section{DISCUSSION}

The results of our research showed a continuing high pollen beetle resistance to the tested pyrethroids: deltamethrin and beta-cyfluthrin. This is confirmed by the results of other authors (Detourne et al. 2002; Ballanger and Delorme 2005; Heimbach et al. 2006a, 2006b; Kazachkova 2007; Slater and Nauen 2007; Hansen 2008; Richardson 2008; Tillikainen and Hokkanen 2008; Węgorek 2009). There has been a widespread problem with pollen beetle resistance to pyrethroids in Europe during the last ten years (Detourne et al. 2002; Hansen 2003; Węgorek 2005; Heimbach et al. 2006a; Richardson 2008; Tillikainen and Hokkanen 2008;). Field research in Poland noted that at registration time, the effectiveness of pyrethroids against the pollen beetle was very high (Witkowski et al. 1988, 1989a 1989b; Pruszyński and Mrówczyński 1990; Mrówczyński et al. 1997; Seta et al. 1997). A significant decrease in the pollen beetle susceptibility level to different pyrethroid active substances was found by Węgorek (Węgorek 2009). The research presented by Węgorek showed that $\mathrm{LC}_{50}$ values for deltamethrin ranged from $47 \mathrm{ppm}$ to $87 \mathrm{ppm}$, $\mathrm{LC}_{95}$ from $164 \mathrm{ppm}$ to $360 \mathrm{ppm}$, and that the resistance coefficient values ranged from 6 to 14. In our research, $\mathrm{LC}_{50}$ values for deltamethrin were between $20 \mathrm{ppm}$ and 46 ppm, LC $_{95}$ values were between 108 ppm and 809 ppm, and resistance coefficient values were between 4 and 32 . Similar slight differences were also visible in the results of research on beta-cyfluthrin. It can be concluded, that pollen beetle resistance level to deltamethrin and betacyfluthrin has maintained the same, high level for the last few years. When taking into consideration such a high resistance level, an ineffectiveness of the treatments in the fields can be expected.

Pollen beetle resistance mechanisms to pyrethroids and other insecticide active substances have already been investigated, both in Poland and in other European countries (Nauen 2007; Skillman 2007; Węgorek 2009; Phillippou et al. 2010; Węgorek et al. 2011a). The main mechanism of resistance to pyrethroids was found to be the one based on oxidative enzymes. In our research, blocking oxidative enzymes with PBO resulted in a much better effectiveness of deltamethrin. Similar results on cooperation between PBO and pyrethroid active substances (esfenvalerate, lambda-cyhalothrin, zeta-cypermethrin, beta-cyfluthrin, cypermethrin and tau-fluvalinate) against the pollen beetle were obtained earlier (Węgorek 2009; Węgorek et al. 2011a). Such results do not exclude participation of esterases, because PBO is also known to be an esterases blocker (Gunning et al. 1998). However, other scientific papers emphasis that PBO is mainly an oxidative enzymes blocker and only slightly inhibits esterases (Schoknecht and Otto 1989; Malinowski 2003). In light of this, our results showing high synergism between deltamethrin and PBO prove that not only oxidases, but also some esterases take part in the pyrethroid detoxificatoion.

In our research, an increase in deltamethrin toxicity was also found after blocking esterases with DEF. This effect was not as high as in the case of PBO but it can be concluded that the resistance mechanism based on esterases, is also involved in deltamethrin detoxification. So far, in Poland, the participation of esterases in the pollen beetle resistance mechanisms has been tested only with the use of carbaryl. The results did not clearly indicate that esterases blocked with carbaryl so as to participate in the pyrethroid detoxification (Węgorek 2009; Węgorek et al. 2011a). Such results do not exclude the participation of other esterases. The results of the research presented in this study prove the participation of esterases blocked with DEF, in the deltamethrin detoxification of the pollen beetle for the first time. DEF may also block acetylcho- 
linesterase, and so it may act as an insecticide. However the concentrations of the blockers used in this study had been estimated before starting the experiments, as the ones that did not cause any insect mortality when used without insecticides. The role of esterases in insecticide detoxification mechanisms in different insect pests was also shown by other authors (Devonshire and Field 1991; Whyard et al. 1994; Parker et al. 1996; Gunning et al. 1998).

The results of the presented studies also confirmed the role of glutathione transferases - enzymes taking part in the second phase of the biotransformation of toxins in the pollen beetle resistance mechanisms to deltamethrin. It is important to note, though, that the synergism coefficient was much lower than in the case of $\mathrm{PBO}$ and DEF, proving the slight participation of glutathione transferases in deltamethrin detoxification. Little is known about the role of glutathione transferases (GST) in pyrethroids detoxification. Generally, highly specialized insects which feed on a small group of plants, most often have only one form of GST isoensymes, while poliphagues usually have 4-9 forms of GST isoenzymes (Ottea and Plapp 1984; Clark et al. 1986; Ranson and Hemingway 2005). Probably, the narrow feeding specialization of the pollen beetle is the reason for the slight role of glutathione transferases in deltamethrin detoxification.

Resistance to different insecticide active substances, created by different insect species, is usually based on several mechanisms (Pospischil et al. 1999; McAbee et al. 2004). The presented research proves that the pollen beetle has a very strong metabolism potential that may create even more problems in rapeseed protection in the future. Resistance mechanisms, based of the already proven activity of the enzymes, can be used in plant protection by choosing active substances, whose metabolites (arising under the influence of enzymes responsible for resistance) are much stronger toxins than the starting material. Nowadays in Poland, this has been done in the case of chlorpiryfos, whose metabolite is a much stronger insecticide. That is why constant monitoring of the susceptibility level, detecting resistance mechanisms, and searching for synergists that could be used in overcoming resistance, should be stable directions of scientific research.

\section{REFERENCES}

Ahmad S. 1986. Enzymatic adaptations of herbivorous insects and mites to phytochemicals. J. Chem. Ecol. 12 (2): 533-560.

Ballanger Y., Delorme R. 2005. Meligethes des cruciferes (Meligethes aeneus F.): ultimes solutions insecticides. p. 10. In: 07eme Conference Internationale sur les Ravageurs en Agriculture, Montpellier, 26-27 Octobre, 220 pp.

Clark A., Shamaan N., Sinclair M., Dauterman W. 1986. Insecticide metabolism by multiple glutathione S-transferases in two strain of the house fly, Musca domestica L. Pestic. Biochem. Physiol. 25 (2): 169-175.

Detourne D., Delorme R., Ballanger Y. 2002. Resistance des meligethes du colza: bilan de 3 annees d'enquete. p. 667-674. In : 06eme Conference Internationale sur les Ravageur en Agriculture, Montpellier, 4-6 Decembre 2002, 123 pp.
Devonshire A.L., Field L.M. 1991. Gene amplifications and insecticide resistance. Ann. Rev. Entomol. 36: 1-24.

Gunning R., Moores G., Devonshire A. 1998. Inhibition of resistance related esterases by piperonyl butoxide in Helicoverpa armigera (Lepidoptera: Noctuidae) and Aphis gossypii (Hemiptera: Aphididae). p. 215-226. In: "Piperonyl Butoxide. The Insecticide Synergist" (D. Jones, ed.). Academic Press, London, UK, 323 pp.

Hansen L. 2003. Insecticide-resistant pollen beetle (Meligethes aeneus F.) found in Danish rape (Brassica napus) fields. Pest Manage. Sci. 59 (9): 1057-1059.

Hansen L.M. 2008. Occurrence of insecticide resistant pollen beetles (Meligethes aeneus F.) in Danish oilseed rape (Brassica napus L.) crops. Bull. OEPP/EPPO Bull. 38 (1): 95-98.

Heimbach U., Müller A., Thieme T. 2006a. First steps to analyse pyrethroid resistance of different oilseed rape pests in Germany. Nachrichtenbl. Pflanzenschutz. 58 (1): 1-5.

Heimbach U., Müller A., Thieme T. 2006b. First steps to analyse pyrethroid resistance of different oilseed rape pests in Germany: an extended abstract. IOBC/WPRS Bull. 29 (7): 131-134.

Kazachkova N.I. 2007. Genotype analysis and studies of pyrethroid resistance of the oilseed rape (Brassica napus) insect pest - pollen beetle (Meligethes aeneus). Ph. D. thesis. Swedish University of Agricultural Sciences. Uppsala, 56 pp.

Malinowski H. 2003. Odporność Owadów na Insektycydy. Mechanizmy Powstawania i Możliwości Przeciwdziałania. Wyd. Wieś Jutra, 211 pp.

McAbee R.D., Kang K.D., Stanich M.A., Christiansen J.A., Wheelock C.E., Inman A.D., Hammock B.D., Cornel A.J. 2004. Pyrethroid tolerance in Culex pipiens pipiens var molestus from Marin County, California. Pest Manage. Sci. 60 (4): 359-368.

Mrówczyński M., Widerski K., Wachowiak H., Banaszak H., Głazek M., Seta G., Pietryga J., Sieńkowski A., Zachmann A., Gawroński P. 1997. Badania nad łącznym stosowaniem środków ochrony roślin z nawozami dolistnymi typu Basfoliar i Solubor DF. [Studies on usefulness of joined application of deltamethryn with Basfollar type fertilizers in modern technologies of agricultural plant production]. Prog. Plant Prot./Post. Ochr. Roślin 37 (2): 68-73.

Nauen R. 2007. Insecticide mode of action, incidence and mechanisms of resistance. Presentation Abstract, EPPO Workshop on insecticide resistance of Meligethes ssp. (pollen beetle) on oilseed rape. Berlin, 3-5 September 2007. www.archives. eppo.org/MEETINGS/2007. Accessed: 22 July 2012.

Ottea J., Plapp Jr. F. 1984. Glutathione S-transferase in the housefly: biochemical and genetic changes associated with induction and insecticide resistance. Pestic. Biochem. Physiol. 22 (2): 203-208.

Parker A.G., Campbell P.M., Spackman M.E., Russel M.J., Oakeshott J.G. 1996. Comparison of an esterase associated with organophosphate resistance in Lucilia cuprina with an orthologue not associated with resistance in Drosophila melanogaster. Pestic. Biochem. Physiol. 55 (2): 85-95.

Philippou D., Field L., Węgorek P., Zamojska J., Andrews M., Slater R., Moores G. 2010. Characterising metabolic resistance in pyrethroid - insensitive pollen beetle (Meligethes aeneus F.) from Poland and Switzerland. Pest Manage. Sci. 67 (2): 239-243. 
Pospischil R., szomm K., Londershausen M., Schroder I., Turberg A., Fuchs R. 1999. Multiple resistance in the Larger House Fly Musca domestica in Germany. Pest. Sci. 48 (4): 333-341.

Pruszyński S., Mrówczyński M. 1990. Trial results on use of lambda-cyhalothrin for pest control in agricultural crops in Poland. The BCPC Conference - Pest and Diseases 2: 715-720.

Ranson E., Hemingway J. 2005. Glutatione transferases. p. 403410. In: “Comprehensive Molecular Insect Science” (L. Gilbert, K. Iatrou, S. Gill, eds.). Oxford, Elsevier, 410 pp.

Richardson D.M. 2008. Summary of findings from a participant country pollen beetle questionnaire. Bull. OEPP/EPPO Bull. 38 (1): 68-72.

Schoknecht U., Otto D. 1989. Enzymes involved in the metabolism of organophosphorous, carbamate and pyrethroid insecticides. Chem. Plant Prot. 2: 117-156.

Seta G., Drzewiecki S., Mrówczyński M., Widerski K., Wachowiak H. 1997. Badania nad zastosowaniem nowych insektycydów w zwalczaniu szkodników rzepaku ozimego. [Study on effectiveness of new insecticide proteus $110 \mathrm{OD}$ in tank-mix application with the period of flowering and pods formation of winter oilseed rape]. Prog. Plant Prot./ Post. Ochr. Roślin 37 (2): 96-99.

Skillman W.S. 2007. Use of the synergist piperonyl butoxide in combination with a pyrethroid insecticide lambda-cyhalothrin against metabolically resistant pollen beetle, Meligethes aeneus. Presentation Abstract, EPPO Workshop on insecticide resistance of Meligethes ssp. (pollen beetle) on oilseed rape. Berlin, 3-5 September 2007. www.archives. eppo.org/MEETINGS/2007. Accessed: 18 September 2012.

Slater R., Nauen R. 2007. The development and nature of pyrtehroid resistance in the pollen beetle (Meligethes aeneus) in Europe. Presentation Abstract, EPPO Workshop on insecticide resistance of Meligethes ssp. (pollen beetle) on oilseed rape. Berlin, 3-5 September 2007. www.archives.eppo.org/ MEETINGS/2007. Accessed: 14 March 2012.

Terra W., Ferreira C. 2005. Biochemistry of Digestion. p. 171-224. In: "Comprehensive Molecular Insect Science 4" (L. Gilbert, K. Iatrou, S. Gill, eds.). Oxford, Elsevier, 507 pp.

Tillikainen T.M., Hokkanen H.M.T. 2008. Pyrethroid resistance in Finich pollen beetle (Meligethes aeneus) populations - is it around the corner? Bull. OEPP/EPPO Bull. 38 (1): 99-103.

Węgorek P. 2005. Preliminary data on resistance appearance of pollen beetle PB (Meligethes aeneus F.) to selected pyrethroids, organophosphorous and chloronicotynyls insecticides, in 2004 year in Poland. Resistant Pest Manage. Newsletter 14 (2): 19-21.
Węgorek P., Zamoyska J. 2008. Current status of resistance in pollen beetle (Meligethes aeneus F.) to selected active substances of insecticides in Poland. Bull. OEPP/EPPO Bull. 38: 91-94.

Węgorek P. 2009. Badania nad odpornością chrząszczy słodyszka rzepakowego (Meligethes aeneus F.) na insektycydy. Rozpr. Nauk. IOR - PIB 20, 122 pp.

Węgorek P., Mrówczyński M., Zamojska J. 2009. Resistance of pollen beetle (Meligethes aeneus F.) to selected active substances of insecticides in Poland. J. Plant Prot. Res. 49 (1): 119-127.

Węgorek P., Zamojska J., Mrówczyński M. 2011a. High resistance to pyrethroid insecticides in Polish pollen beetle (Meligethes aeneus F.) - the role of oxidative metabolism. Phytoparasitica 39 (1): 43-49.

Węgorek P., Zamojska J., Mrówczyński M. 2011b. Susceptibility level of the Colorado potato beetle (Leptinotarsa decemlineata Say) to chlorpyrifos and acetamiprid in Poland and resistance mechanisms of the pest to chlorpyrifos. J. Plant Prot. Res. 51 (3): 279-284.

Whyard S., Downe A., Walker V. 1994. Isolation of an esterase conferring insecticide resistance in the mosquito Culvex tarsalis. Insect Biochem. Molec. 24 (8): 819-827.

Witkowski W., Ciesielski F., Mrówczyński M., Wachowiak H. 1988. Zastosowanie pyretroidów do zwalczania słodyszka rzepakowego Meligethes aeneus F. Wyniki badań nad rzepakiem ozimym - rok 1987. Zesz. Probl. 2. Rośliny Oleiste IHAR, Radzików: 377-390.

Witkowski W., Ciesielski F., Mrówczyński M., Wachowiak H. 1989a. Skuteczność pyretroidów w zwalczaniu słodyszka rzepakowego Meligethes aeneus F. w Polsce. Materiały 29. Sesji Naukowej Inst. Ochr. Roślin, cz. 1: 141-154.

Witkowski W., Ciesielski F., Mrówczyński M., Wachowiak H. 1989b. Zastosowanie związków fosforoorganicznych do zwalczania słodyszka rzepakowego. Wyniki badań nad rzepakiem ozimym - rok 1988. Zesz. Probl. 2. Rośliny Oleiste IHAR, Radzików: 341-348.

Yu S.J. 1988. Enzyme induction as detoxication mechanism in phytophagous insects. Bull. Institute of Zoology Academia Sinica 13: 49-68.

Zamojska J., Węgorek P., Mrówczyński M. 2010. Obecny poziom odporności na insektycydy dla wybranych gatunków owadów w Polsce. [Current status of a threat by resistance to insecticides of selected insect species in Poland]. Prog. Plant Prot./Post. Ochr. Roślin 50 (3): 1205-1212.

Zamojska J., Węgorek P., Mrówczyński M. 2011. Changes in the Colorado potato beetle (Leptinotarsa decemlineata Say) susceptibility level to pyrethroids and the pest resistance mechanisms to deltamethrin. J. Plant Prot. Res. 51 (3): 294299. 